Przegląd Badań Edukacyjnych

Educational Studies Review

ISSN 1895-4308

nr 28 (1/2019), s. 161-176

METAANALIZY

BADAŃ

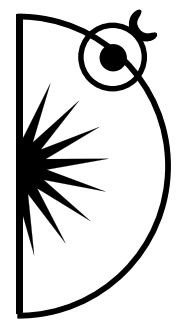

Marzenna Zaorska

ORCID: 0000-0003-4867-770X

University of Warmia and Mazury in Olsztyn; e-mail: mzaorska@poczta.onet.pl

\title{
In Search for Optimal Educational, Rehabilitative and Supportive Solutions for People with Disabilities in the Context of Postulates Put Forward in the International Classification of Functioning, Disability and Health (ICF)
}

http://dx.doi.org/10.12775/PBE.2019.009

\begin{abstract}
This paper is mainly focused on the analysis of the issue of human disability as a phenomenon and condition and in the context of contemporary tendencies of interpreting disability postulated by the International Classification of Functioning, Disability and Health (ICF) (2001). Attention is paid mostly to the issue of blurring the borders between non-disability and disability in relation to meeting the needs of people identified as non-disabled and disabled, as well as dangers resulting from such an approach.
\end{abstract}

Key words: disability, the notion of disability, the condition of disability, disabled person, needs, the needs of disabled people.

\section{Introduction - the specificity of the modern approach to the phenomenon of human disability}

As human civilization continually develops, the notion of human disability constantly changes in line with tendencies dominating in specific historical periods. These tendencies are conditioned, along with other factors, by the scientific and 
technological progress, as well as new concepts of how to define the essence, meaning and determinants of the quality of human life. Modern times are characterized by the unprecedented pace of the development of science and new technologies, including those that are questionable from a humanistic, ethical and moral point of view, e.g., technologies involving research on human embryos, cloning (so far of animals only), technologies that improve the functioning and physical capabilities of the body through the cyborgization of the human organism. Additionally, modern times are also characterized by the constantly increasing level of material existence and a simultaneous renouncement of traditional and universal values.

Presently disability is perceived as a phenomenon determined primarily by social factors, and these factors are decisive in assessing the severity of the outcomes of disability and the required range, duration and expected effectiveness of the offered educational, medical, therapeutic, rehabilitative, social and vocational support. This means a departure from, or at least minimization of biological and medical aspects and dimensions of a reduced capacity or disability of the human organism. However, the declared departure from the biological aspect appears highly questionable, since the presently adopted model of disability is defined as a bio-psycho-social one. This situation finds its exemplification and confirmation in the International Classification of Functioning, Disability and Health (ICF) introduced in 2001 by the World Health Organization to describe disability and the needs of people with disabilities, which is structured on this model. ICF not only analyzes the human being from the perspective of three basic dimensions of existence, but also transfers the data analysis on the interpretation of the outcomes of disability and the needs of people with disabilities as regards broadly understood medical, psychopedagogic, technical and social support in the assumed dimension. ICF postulates that a human being is a biological (the body of a specific structure and fulfilling specific functions - organism functioning), active (a person who acts and executes particular life actions and tasks), and social (a member of a particular social group to which one belongs and participates in its life) being. Considering this conception of a human being, the description of disability accounts for the biological dimension (absence, limitation or impairment of the organism functions depending on the severity and range of damage to its organs or systems), individual/personal dimension (limitation in activity), and social dimension (limited participation in social life - social functioning). The very theses concerning the essence of the human being imply that this conception may be perceived as materialistic, atheistic and largely neo-Marxist. 
In the perception and interpretation, and consequently in the assessment of supportive activities, ICF considers interactions between components of health and some health-related components of wellbeing (such as education and labor), organism functioning (a person's activity and participation in social life; ICF determines positive aspects of interactions between a person in a given health situation and contextual/situational factors - these are environmental factors and personal factors that impact on the good functioning of an individual) (ICF, 2009, p. 7). Disability is an umbrella term encompassing all types of impairments (cf. ICF, 2009, p. 7), activity limitations and participation restrictions as regards social life ${ }^{1}$. At this point one may conclude that because the outcomes of disability are placed in the social domain, the understanding of disability as any departure from the established norm that limits activity and participation becomes blurred. Extraordinary capabilities may also be perceived as a departure that limits activity and restricts social participation relative to not meeting the needs that result from these extraordinary capabilities. Thus, every person, if not permanently, then at least temporarily, while not being disabled from a biological point of view, may be disabled due to the criterion of a limited or restricted activity in relation to capacities, thus not fulfilling one's potential, and not meeting one's developmental and capability needs as regards the participation in social life. Consequently, if each person is or may be qualified as disabled, it is not surprising that in the domain of education it is postulated that one universal core curriculum should be designed for all pupils (forgetting at the same time that such a solution itself becomes a developmental restriction both for non-disabled and disabled pupils).

Presently, in promoting the approach put forward in ICF, the idea to abandon, or at least maximally depart from nosologic analyses of disabilities in order to privilege functional ones is advanced (Zaorska, 2015). This means abandoning the identification of disability based on the criterion of its type and severity for the sake of identifying existing needs in the domain of required support, which - if not met - may lead to barriers, limitations or restrictions in personal and social activities. Following this train of thought, presently it is no

${ }^{1}$ Presently, different definitions of the terms "disability" and a "disabled person" may be found in the existing international and Polish legislation as well as in scientific literature devoted to special needs education. This is exemplified by the definition of disability adopted by the Convention on the Rights of Persons with Disabilities (2006). Simultaneously, a tendency in political activities (and legislative ones) appears to include the postulates promoted by the International Classification of Functioning, Disability and Health (ICF, 2009). Hence, I refer to the definition of disability taken from ICF. 
longer possible to talk about intellectual disability and its degrees, about hearing, visual and other impairments, but only about needs which - when unfulfilled due to the existing internal and external barriers (mostly external) - lead to difficulties, limitations and incapacities. This demolishes the traditional perception of special needs education and the identification of its structure through sub-disciplines created on the basis of the type of disability. Approaches based on functional and supportive parameters are suggested instead. Simultaneously, expectations as regards the education and competences of special needs educationists appear, constructed on the functional-supportive model that does not account for nosologic determinants in defining disability. The described postulate appears not only very difficult but may be actually impossible to implement. It is a postulate that conceals political correctness in approaching disability; it is devoid of meaning and in some circumstances may be dangerous for both non-disabled and disabled individuals. In the case of people with disabilities it expresses the departure from an objective (including medical) description of their factual functioning and thus the existing needs. In the case of non-disabled individuals, it makes them disabled, determining their needs that require special fulfilment due to their non-disability.

The ICF conception has found its exemplification in the Convention on the Rights of Persons with Disabilities (2006), especially in the entries that serve to ensure equality of opportunity for people with disabilities, prevent their discrimination and ensure equal rights as concerns people with and without disabilities. For instance: respect for inherent dignity, individual autonomy including the freedom to make one's own choices, and independence, full and effective participation in society and inclusion in society, respect for difference and acceptance of people with disabilities as part of human diversity and humanity, accessibility, reasonable accommodation, universal design etc. (Convention on the Rights of Persons with Disabilities, 2006).

It is obviously beyond doubt that the enumerated notions and the intention behind the requirement to meet them are legitimate. Such doubts appear, however, as regards the tendencies towards the functional description of disability and the exemplification of its social contexts. Such an approach may turn disability into an essentially social and situational problem and present its overriding sense in the context of environmental barriers and needs that will result in disability disappearance when such are overcome and met, respectively. This is exemplified by a postulate, actually justifiable in itself, to treat disability as one of many features of a human being (a disabled person), expressed in the phrase "person with a disability". However, a question arises whether this person re- 
mains disabled or not when this feature disappears as assessed from a social and functional point of view due to appropriate support provided.

To conclude these deliberations, one can notice contemporary tendencies towards the effacement of borders between the condition of non-disability and disability due to an essentially social vision of human functioning. This vision promotes the anchoring of possible problems of individuals in environmental and social conditions, the removal of which, thanks to appropriate support, will make a person with disabilities equally active as a person without disabilities and vice versa.

\section{Diversity of disabilities and diversity of needs of people with disabilities}

Generally, disability as a phenomenon and condition, depending on its type and severity, generates equivocal, diverse, and unique needs, but also needs related to individualized expectations. Psychology conceives human needs in the categories of initiators and indicators of human activity. Needs appear when a person experiences the lack or excess of something in relation to the required optimal living conditions (homeostasis). Thus, needs are definitely a source of activity; however, none of human needs stems directly from human nature, but each develops processually as a result of the interaction with the external world (Szewczuk, 1998). The simplest categorization of needs differentiates between inherent and acquired needs. The former - biological needs - refer to the human organism and appear due to innate mechanisms in the situation of a lack or excess of a factor with or without which existence is impossible. Despite their biological nature, they are more or less socially conditioned. The latter - acquired social needs - appear during a person's lifetime and are shaped depending on the existential situation and socio-cultural contexts. They are socially conditioned and individualized. Thus, human needs are defined through interactions between social and biological factors. They determine one's activity, keep one alive and shape one's individual character.

These assumptions allow us to consider the issue of the needs of people with disabilities both in the general context, i.e., bound with the phenomenon and condition of disability, as well as in the specified context, i.e., focused on a specific type of disability, and then to refer the conclusions to the postulates contained in ICF.

Needs of people with disabilities (following the idea of universal and specific problems of special needs education as proposed by Aleksander Hulk, 
1980) may be divided into universal and specific. Universal needs embrace all categories of disabilities, are of a generalized and synthetic nature, and characterize disability in general terms. Essentially, these needs are expressed through the parameter of particular (sometimes increased) needs as regards care and the right to receive care, through which a disabled person may fully develop and achieve maximal social recognition; their fulfilment should be adapted to the condition of disability. Educational, rehabilitative and therapeutic activities should be optimized so that the person might autonomously execute various social tasks, achieve self-realization, and follow one's own life path, be maximally independent of social (including financial) support and other people. Specific needs, similar to universal needs, may be categorized as inherent and acquired. Their specificity lies in an accounting for the type of disability and severity of its outcomes. This specificity refers also to the interpretation of the semantic field of these needs, their space and the manner of fulfilment. Those needs manifested by people with sensory, psychiatric and intellectual disabilities are, after all, specific and so are the mentioned criteria. The needs of people with intellectual disabilities and visual impairments are met differently and are non-identical; just as the needs of people with mild and profound intellectual disabilities as well as the needs of the blind and people with visual impairment. It should also be stressed that the nature of needs, both universal and specific ones, is individualized (they refer to a particular person with disabilities) - in line with a biographical paradigm of disability (Dykcik, 2009).

Referring the presented way of thinking about the needs of disabled people to the general population, without distinguishing between disabled and nondisabled people, human needs may be divided into universal and specific. Universal needs are the needs of every person (inherent and acquired), whereas special needs are conditioned and generated by the impact of the environment and personality; they are individualized and exemplified by qualitative and quantitative criteria, range and type of needs, preferences as to dominant needs and the manner of their fulfilment. These are, for instance, needs concerning self-realization, development of one's skills and talents, desired physical and social activity, quality of life, spending leisure time, as well as the expected economic, educational and professional status.

The conclusions arising from the conducted analysis as to the needs of disabled people may be juxtaposed with the postulates contained in ICF, especially the postulate to abandon nosologic terminology (i.e., categorization of types of disabilities and their severity) and to describe disability through the categories of necessary support in relation to functional (situational) barri- 
ers, embracing environmental factors and personality traits. If, as stated above, a broad interpretation of the phenomenon and condition of disability is applied, implying that the notion of disability may refer to each person and each person may be perceived as disabled (e.g., temporarily, periodically or in specific aspects of functioning), the danger of blurring differences between non-disability and disability appears. In other words, deliberations as to the specificity of the needs of people with disabilities become groundless. If any specificity is to be indicated, it would need to embrace qualitative and quantitative criteria, since all people have identical needs. Quantitative criteria refer to the frequency of required supportive activities, while qualitative criteria point to their intensity.

The presented interpretations are exemplified by the current approach to special educational needs. This approach assumes that special educational needs refer to all children, because each child has his or her own special and unique educational needs that should be met by means of targeted solutions offered by the system of education. At the same time, the postulate of the so-called inclusive education is put forward, embracing (according to the presented interpretations) all pupils. As studies conducted by the European Agency for Special Needs and Inclusive Education indicate, good quality education is adapted to the needs of all pupils (Pięć kluczowych przesłań edukacji włączającej. Od teorii do praktyki [Five Key Messages for Inclusive Education. Putting Theory into Practice], 2014, European Agency for Special Needs and Inclusive Education) ${ }^{2}$. A school that responds to the needs of pupils with special educational needs

${ }^{2}$ In Polish scientific literature concerning the issue of the so-called special educational needs (Janiszewska-Nieścioruk, 2014, Sadowska, Janiszewska-Nieścioruk, 2018, Szumski, 2006, Zaorska, 2009, 2014, 2017), but also in the regulations of the Ministry of National Education (Regulation of the Minister National Education of 16 August 2018 changing the Regulation on the organization and providing psychological and pedagogical support in state-owned preschools, schools and institutions, Journal of Laws 2018, item 1647; Regulation of the Minister of National Education of 9 August 2017 on organization and providing psychological and pedagogical support in state-owned preschools, schools and institutions, Journal of Laws 2017, item 1591) a different approach to the categorization of pupils with special educational needs is presented from that proposed by the European Agency for Special Needs and Inclusive Education. Its essence is to identify in the group of pupils with special educational needs those pupils who, due to their developmental disorders, emotional disturbances, disabilities, chronic diseases, behavioral and socialization problems, cultural differences, risk of social maladjustment, crisis and traumatic situations, environmental neglect, experience problems with learning content included in the core curriculum and require additional, diversified, individualized, psychological and pedagogical support adapted to capacities and experienced difficulties, essentially provided at school, psychological and pedagogical outpatient clinic or other specialist outpatient clinic. This group includes also gifted and talented students. 
provides better teaching for all pupils. However, a doubt arises here as to which pupils the European Agency for Special Needs and Inclusive Education refers to since all pupils have special educational needs.

The issue of the needs of people with disabilities as analyzed here may be also problematic for parents of adult disabled individuals unable to work, who fight for increasing benefits received by their children from the state. The presented approach to the needs of disabled people is discordant with these parents' expectations since the border between non-disability and disability becomes blurred and when supportive activities are rationalized depending on the financial possibilities of the state. After all, all citizens have the right to receive support under the principle of social solidarity and social justice, understood as the right of all citizens to benefit from the common good generated by society. Considering the above, further doubts appear as to the postulates articulated in the conception of human disability as proposed by ICF.

\section{Disability and non-disability in the context of social status and needs}

Disability as a social phenomenon and as a condition pertaining to a given individual is relevant not only to the discussion concerning the needs of disabled people in relation to the needs of non-disabled people, but also to the social status of both disabled and non-disabled people in the context of meeting their needs. It should be observed that the position of disabled people as regards their social status is very complicated as it is inextricably bound with individual health conditions and functional barriers within a given person herself/himself and within her/his social environment. This position may be (and mostly is) determined by generally not very favourable social attitudes. This contributes to stigmatization and marginalization as well as limiting the possibilities of selfrealization and impacting negatively on the quality of life.

Social justice is understood as a feature of the political system and legal order. It is characterized by objectified criteria of assessing rights and duties, identical for all citizens and social groups. It is also perceived as a feature of social relations. In that case it is the manner of treating particular groups and individuals on the grounds of their social class, nation, religion, race, gender, etc. and refers to: equality or non-equality of social groups and their members as well as the assessment of whether the principles and criteria of the distribution of wealth, influence, power and spiritual values (authority, appreciation, prestige) are fair and adequate. The understanding of the concept of social jus- 
tice depends on a given culture and civilization, historical epoch, interests and mentality of particular nations, religious and regional groups, and on local traditions. The manner and degree of the implementation of the concept of social justice are conditioned by the interpretation of its sense and by the political lineup. A common feature of dissimilar conceptions of and approaches to social justice is, however, linking the principle of responsibility for the common good of a nation and humanity (public interest) with the principle of human solidarity. What is postulated in terms of human relationships is the elimination of evilness exploitation, repression and violence, non-discrimination due to race, gender, religious beliefs, and political views, abolishment of undeserved social privileges, ensuring equality of opportunities and equal rights for all, as well as preventing one to live at the expense of others (Strzyczkowski, 2007).

The principle of a social justice state is a meta-norm functioning as a general constitutional principle. This means the inclusion of a social justice state into constitutional values set forth by the social contract and determines the type of axiology preferred in the activities of the state (Strzyczkowski, 2007, p. 14). By virtue of this principle the state is obliged to establish a fair social order, in particular to equalize social differences and ensure social protection through social securities (Strzyczkowski, p. 17). The principle of social justice is linked with the principles of dignity and the equality of people. Dignity is "inherent and inalienable" as well as "inviolable" and is the source of "human rights and liberties". It is the supreme normative principle (Strzyczkowski, s. 12) and an effective protection of human dignity requires the principle of social justice to be observed (Strzyczkowski, p. 13). The principle of equality is at one with enjoying equal rights, but also with a rationalized (accounting for the life situation of a given person) distribution of the common good generated by society. Consequently, within the framework of a social justice state, subjective rights must be respected, especially the right to equality. The fulfilment of the principle of equality is determined by the need to protect human dignity that requires observing not only the principle of the rule of law, but also the principle of a social justice state (Strzyczkowski, p. 15). However, throughout human history (from Aristotle to the views of other thinkers in the following epochs, e.g., Jeremy Bentham, John Stuart Mill, Herbert Spencer) the concept of social justice was (and still is) perceived as very difficult to define and "fuzzy", thus it is understood differently depending on specific philosophical and political views (e.g., definitions set forth by Utilitarianism, Marxism) (Wróbel, 2013).

Chaïm Perelman (1959), a Belgian lawyer and philosopher of law, differentiated at least six principles and criteria ensuring that each entity is treated equally: 
1. To each the same thing - all entities that are the subject of justice belong exclusively to the same relevant category (a stricte egalitarian formula);

2. To each according to his merits - entities belonging to the same relevant category should be treated equally (in the same degree) according to comparable merits;

3. To each according to his works - individuals whose work, according to a particular judge, has the same value, i.e., those who belong to the same relevant category, should be treated equally (e.g., the postulate of equal pay for laborers for their work);

4. To each according to his needs - this formula demands equal treatment of people who belong to the same relevant category due to their needs;

5. To each according to his ranks - this conception is based on the assumption that people are divided according to class, which is not necessarily hierarchical; members of different classes should be treated differently, but members of the same class, i.e., of the same relevant category, should be treated equally;

6. To each according to his legal entitlement - a person who applies this formula cannot choose the conception of justice that one prefers but must observe established norms (Perelman, 1959; cf. Wróbel, 2013, p. 141).

Generalizing Chaïm Perelman's views, the distribution of the common good generated by society may be limited to three principles: to each the same thing (all people should be treated equally, irrespective of individual differences in their contribution and needs), to each according to his needs (intentions and needs of the person should be mostly rewarded, and the result of work is less significant), to each according to his merits (people should be treated in proportion to the results of their work) (cf. Wróbel, 2013, p. 141).

How, in the context of the presented theses, can the situation and needs of disabled people and those related to them be interpreted as regards social, financial, supportive, educational and rehabilitative securities as well as the fulfilment of their needs? A humanistic approach to the human being prioritizes the principle of "to each according to his needs". This would account for the specific health, life and social situations of such people, for the principle of social solidarity consisting in sharing goods with those in need, for increased needs of disabled people in specific dimensions and ranges, and for the acceptance of not observing the principles of "to each the same thing" and "to each according to his merits". Consent to the implementation of this assumption may be of a social and individual nature or of a social and individual nature enforced 
by legislation, political decisions, and the organization of the state. In the latter situation such consent does not stem from the conviction that the conventions of humanism are well-grounded but possesses the dimension of humanism sanctioned by the need to act according to humanistic principles. Obviously, such an approach and conduct may be objected to by some social groups or individuals and may evoke feelings of unfairness and working for the sake of those who contribute less to society.

Due to various issues aforementioned, a problem with translating the postulates of social justice and solidarity into the postulates of ICF appears. It may be concluded that in some aspects ICF promotes the principle "to each according to his needs", considering the range of necessary support in relation to internal barriers (inherent in the disabled person) and external barriers (environmental) and assesses the needs of a disabled person on the basis of the criterion of experienced difficulties. On the other hand, ICF deforms this principle through the tendency towards blurring the borders between non-disability and disability, speciality and non-speciality, and towards needs homogenization. This leads to the conclusion that all citizens must participate in the distribution of the common good generated by society, because all people have their special needs (although diverse in terms of range and quality) and have the right to expect that their needs will be met according to the principles of social justice and solidarity.

\section{Equal treatment through accounting for differences in the needs and capacities of non-disabled and disabled people}

Rationalization of supportive activities may eliminate the dissonance between the rights of non-disabled and disabled people to meet their needs by a state based on fairness and solidarity. Such rationalization would account for differences in the needs and capacities of all citizens in meeting their needs, while relating the criteria to realize these aims to the objective resources possessed by the state.

This diversity of needs is determined by the criteria of individuality and distinctness. Each person, by virtue of being individual and unique, has one's own physical and personal features, capacities and activities, a specific path in life that one follows and one's own self-realization aims. Individualization and distinctness are linked to the right of each person to receive state support in fulfilling one's needs. The range, intensity, type and duration of this support are defined by the aforementioned criteria. 
Equality of treatment is made manifest in that the state takes into account the diversity of citizens' needs, the right to receive state support in their fulfilment and in the activities undertaken by the state towards fulfilling human needs, while the measures of supportive actions are tailored according to the individualization and distinctness of needs. Consequently, the state fulfils its obligations, and people are treated equally. Their needs are then met according to the expectations and capacities of particular people.

It is obvious that disabled people due to the experienced outcomes of their disabilities and generated barriers both in themselves and in their life and environment require specific activities if their needs are to be met. In the case of such people, we deal with the criterion of individualization and distinctness of needs that refers to all people (both disabled and non-disabled), but also with the criterion of individualization and distinctness modified by disability. The overlapping of these criteria characterizes the specificity of individualization and the distinctness of the needs of people with disabilities. Generally, as in the case of non-disabled people, this specificity is both quantitative and qualitative. It is, however, essentially perceived through the prism of increased supportive actions and larger resources required for their implementation. Higher expenses necessary to meet the needs of disabled people seem to be supported by the indicators of social justice defined in the context of equality that accounts for diversity and distinctness in the framework of qualitative and quantitative criteria.

The thesis of social justice in meeting the needs of disabled people as determined by equality in accepting the right to diversity, implying the individualization of needs that are different for each person, should be then referred to postulates put forward in the International Classification of Functioning, Disability and Health (ICF). ICF describes needs and the range of their fulfilment in the context of determining personal and environmental barriers. Consequently, it may be concluded that when disabled people receive support adequate to their needs generated by the existing and directly experienced barriers, then not only will these needs be completely met, but also such a person's disability will cease to be a disability since disability is understood in the context of internal and external barriers, while nosologic determinants are abandoned. Moreover, given the aforementioned tendency towards the relativization of the borders between non-disability and disability, all people will receive required support under the principle of social justice, and the state will fulfil its obligations towards all citizens. All people will be supported and the principle of equality, distinctness and individualization of needs being its determinants, will be observed. Obviously, such a solution appears excellent from the point of view of a state that has 
limited financial resources and is restricted in the range of the common good generated by society that can be distributed. Whether such a solution rationalizes support offered for disabled people and whether non-disabled people are treated fairly is highly and rightly disputable.

\section{Equality and diversity in the optimization of educational, rehabilitative and supportive solutions}

Another problem arising from deliberations on social justice in meeting the needs of disabled people is the issue of the optimization of actions related to the fulfilment of the needs of particular individuals, constructed on the basis of reliable criteria allowing for such an optimization. It should be observed that optimization does not mean the fulfilment of all demands but embraces their diagnosis in the context of their individualized nature, assessment of difficulties that limit one's personal and social activity, and supportive actions that will maximally eliminate the experienced difficulties so that disabled people will function comparably to non-disabled people. The problem of optimization, however, involves additional determinants that co-decide about supportive needs quantitatively and qualitatively. These are determinants not only directly generated by disability, but also those relating to the actual activity of a given disabled person and the determination of the environment to provide support. The actual activity refers to the disabled person's willingness to act, factually undertaken efforts towards development and self-development, working towards increasing one's physical capacity, acquiring broader and better physical, psychological, social and vocational competencies, the awareness of the necessity to work to improve oneself and such factual work. This is also an approach characterized by striving to be needed by society, to earn one's living if possible, to become independent of social support and other people.

Optimization embraces a broad spectrum of life activities of disabled people, beginning with early developmental support (when disability appears in early developmental stages), through the educational system at the existing levels of education, including life-long learning, to participation in rehabilitation and specialist therapies. Referring these elements to the analyses of distinctness and individuality in meeting the needs of disabled people as determinants of their range, qualitative and quantitative contexts, and also to the argument of the equality of treatment under the principle of social justice, optimization should include the determination and factual efforts of the disabled person to overcome internal and external barriers. These are barriers that limit activity and develop- 
ment and may contribute to the appearance of demanding attitudes exemplified for instance by larger supportive expectations (or even demands) in relation to factually existing needs emerging from the criterion of individualization. Such a situation may also lead to undermining the principle of social justice, evoke objections of those who receive support adequate to their needs, as well as of those who receive support - also adequate - but of a smaller range due to financial limitations.

The described postulates set forth by ICF suggest providing targeted help and optimal support for a disabled person depending on the existing difficulties and barriers. At the same time, these postulates assume that if the barriers and difficulties are properly identified and the support is provided adequately to such identification, such barriers and difficulties should be eliminated. Thus, it will be possible to perceive disability, to put it bluntly, as non-existent, and expectations of additional support in terms of education, rehabilitation, therapy, financial and material aid as illegitimate. Another issue is the extension of disability to the entire population and individualized expectations of particular persons as to receiving support under the principle of social justice. If all people have diverse supportive needs and the right to participate in the distribution of the common good generated by society, then they have the right to expect that the needed support is their due. This may deplete financial resources to be allocated to the disabled people recognized from the nosologic point of view. Thus, postulates articulated in ICF may contribute to the qualitative and quantitative reduction of supportive activities undertaken by the state with respect to disabled people.

\section{Conclusions}

The problem of human disability is multidimensional, multiaspectual, multicontextual and should be interpreted from various, sometimes controversial, and even mutually contradictory, points of view. It is not advisable to perceive disability and the needs of disabled people solely from a biological point of view just as the perception oriented solely on the social criterion is not appropriate. The former limits disability to its medical perspective. The latter may lead to the blurring of differences and borders between non-disability and disability, resulting in treating all people from the perspective of disability and defining disability through the prism of the barriers present in the social environment. The elimination of such barriers will make disability non-existent and all people become (will become) non-disabled. This not only limits the rights of disabled 
people to receive support under the principle of social solidarity, but also extends supportive rights to the population of non-disabled people (making them disabled). Such an approach is not only doubtful from an ethical and moral point of view, but may be also a significant factor limiting a disabled person's personal, social and developmental activities.

\section{References:}

Dykcik, W. (2009). Wprowadzenie w przedmiot pedagogiki specjalnej jako nauki. In: W. Dykcik (ed.), Pedagogika specjalna. Poznań: Wydawnictwo UAM, pp. 13-64.

Hulek, A. (1980). Wspólne i swoiste zagadnienia w rewalidacji różnych grup osób z odchyleniami od normy. In: A. Hulek (ed.), Pedagogika rewalidacyjna. Warszawa: PWN, pp. $462-477$.

Janiszewsk-Nieścioruk, Z., Zaorska, M. (2014). Prowłączające zmiany w systemie polskiej edukacji - nowe możliwości, ograniczenia i wyzwania. Interdyscyplinarne Konteksty Pedagogiki Specjalnej, 4, pp. 9-28. DOI: https://doi.org/10.14746/ikps.2014.4.01

Convention on the Rights of Persons with Disabilities (2006). A/RES/61/106. New York: UN. https:/www.un.org/development/desa/disabilities/resources/general-assembly/convention-on-the-rights-of-persons-with-disabilities-ares61106.html.

ICF (International Classification of Functioning, Disability and Health) (2009). Warszawa: Centrum Systemów Informacyjnych Ochrony Zdrowia.

Perelman, Ch. (1959). O sprawiedliwości. Warszawa: PWN.

Pięć kluczowych przesłań edukacji właczającej. Od teorii do praktyki (2014). European Agency for Special Needs and Inclusive Education.

Regulation of the Minister National Education of 16 August 2018 Changing the Regulation on the Organization and Providing Psychological and Pedagogical Support in State-owned Preschools, Schools and Institutions, Journal of Laws of 2018, item 1647 Retrived 10, February from http://prawo.sejm.gov.pl/isap.nsf/DocDetails.xsp?id=WDU20180001647.

Regulation of the Minister of National Education of 9 August 2017 On Organization and Providing Psychological and Pedagogical Support in State-owned Preschools, Schools and Institutions, Journal of Laws 2017, item 1591. Retrived 10, February form http:// prawo.sejm.gov.pl/isap.nsf/DocDetails.xsp?id=WDU20170001591.

Sadowska, S., Janiszewska-Nieścioruk, Z. (2018). O diagnozie z wykorzystaniem ICF jako 
podstawie organizowania pomocy osobom z niepełnosprawnością - między polityką, wiedzą naukową a praktyką. Niepetnosprawność, 29, pp. 100-114.

Strzyczkowski, K. (2007). Zasada państwa sprawiedliwości społecznej jako zasada publicznego państwa gospodarczego. Ruch Prawniczy, Ekonomiczny i Socjologiczny, 4, pp. 11-16. https://repozytorium.amu.edu.pl/bitstream/10593/5458/1/02_Kazimierz_ Strzyczkowski_Zasada\%20państwa\%20sprawiedliwości\%20społecznej_11-26.pdf

Szumski, G. (2006). Integracyjne ksztatcenie niepetnosprawnych: sens i granice zmiany edukacyjnej. Warszawa: PWN.

Szewczuk, W. (1998). Potrzeby. In: W. Szewczuk (ed.), Encyklopedia psychologii (pp. 432 -436). Warszawa: Wydawnictwo „Fundacja Innowacja”.

Tokarczyk, R. (2005). Filozofia prawa. Lublin: Wydawnictwo UMCS.

Wróbel, P. (2013). Postulat sprawiedliwości społecznej a idea sprawiedliwości społecznej. Studia Socialia Cracoviensia, 5, 1 (8), pp. 135-150. http://dx.doi.org/10.15633/ssc.434.

Zaorska, M. (2009). Dziecko z wadą słuchu w szkole integracyjnej (implikacje dla praktyki). Acta Universitatis Nicolai Copernici, Pedagogika XXIV. Toruń: Nauki Humanistyczno-Społeczne, 392, pp. 117-133.

Zaorska, M. (2014). Uczeń (dziecko) niewidzące i niedowidzące w edukacji inkluzyjnej. Przegląd Badań Edukacyjnych, 1(18), pp. 205-218. DOI: http://dx.doi.org/10.12775/ PBE.2014.014

Zaorska, M. (2015). Potrzeba doprecyzowania terminów istotnych dla praktyki pedagogiki specjalnej i życia osób z niepełnosprawnością. Człowiek - Niepełnosprawność - SpoŁeczeństwo, 3, pp. 19-32.

Zaorska, M. (2017). Dziecko ze specjalnymi potrzebami edukacyjnymi w szkole podstawowej ogólnodostępnej-dyskurs deficyjno-koncepcyjny oraz wybrane sugestie dotyczące organizacji kształcenia. Warmińsko-Mazurski Kwartalnik Naukowy. Nauki Społeczne, 1(21), pp. 11-21. http://www.kwartalnik.wsiie.olsztyn.pl/wp-content/uploads/2018/07/ KW_2017-01-str-11-21.pdf. 